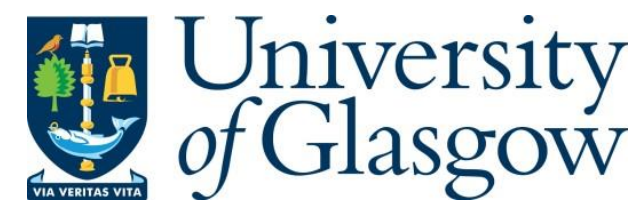

Pittock, M. (2016) Thresholds of memory: Birch and Hawthorn in the poetry of Robert Burns. European Romantic Review, 27(4), pp. 449-458. (doi:10.1080/10509585.2016.1190087)

This is the author's final accepted version.

There may be differences between this version and the published version. You are advised to consult the publisher's version if you wish to cite from it.

http://eprints.gla.ac.uk/120529/

Deposited on: 04 July 2016

Enlighten - Research publications by members of the University of Glasgow http://eprints.gla.ac.uk 


\title{
Thresholds of Memory: Birch and Hawthorn in the Poetry of Robert Burns
}

Murray Pittock, University of Glasgow

\begin{abstract}
Robert Burns’ status as poet sufficiently close to rural poverty to be able to represent himself as its product, and sufficiently distant from it to be able to manipulate that product, is increasingly being realized. In this essay, Burns' use of the country lore associated with the birch and hawthorn trees in Scotland and indeed in Europe more generally, is analysed in terms of its deceptively simple representation of emotion, and the manner in which it acts as a point of access for Burns' view of the tragic status of being human, caught between the cyclical natural world and our own narratives of being, which demand a linear time ending in a 'forever' which on earth can only become loss.
\end{abstract}

How sweetly bloom'd the gay, green birk,

How rich the hawthorn's blossom;

As underneath their fragrant shade,

I clasp'd her to my bosom !

-“Highland Mary” (Kinsley 389)

The view that Robert Burns was a "peasant poet”, of labouring background with poor education and a correspondently limited linguistic resource, dies hard, even if the classification of Burns in this way, as I have argued elsewhere, is itself of relatively recent date (Pittock (2003)). Such an approach is arguably responsible for a good deal of the systemic under-reading Burns has endured. An assumption that he is a 'dialect poet' because of lack of education leads to his complex uses of register and interactive utilization of differing regional dialects being ignored; the view that his copia verborum is not a matter of choice limits interest in its implications; and the 
habit of reading his Scots as denotative rather than connotative, a matter of glossaries and not thesauruses or histories, limits our understanding of the sophistication of the switches and hybridizations in his uses of language (Pittock (2012), 104). Burns was reading Shenstone at sixteen; Akenside, Churchill, Dryden, Fielding, Goldsmith, Johnson, Milton, Otway, Pope, Sterne, Theocritus and Thomson are only some of the authors referenced in his work (Pittock (2003)), while the recent publication by Nigel Leask of Burns’ work in Greek only demonstrates further the deliberation and sophistication of the poet’s reach (Leask (2014), 299-302).

However, Burns was also a countryman, largely a career farmer, and a poet who understood nature intimately, who was infused with the traditions from which he was at the same time detached (as for example in "Halloween” (Kinsley 73) and “Address to the Deil” (Kinsley 76)) (Pittock (2012), 102-04). Nigel Leask’s Robert Burns and Pastoral (2010), which places Burns in the context both of the agricultural practices of his day and the generic representation of the Scottish nation in pastoral terms, found from the seventeenth century onwards, is one of the few studies to address Burns' engagement with the literal and generic values and practices of the land. For as well as a contemporary Romantic poet, at ease with genres and intertexts, Burns was steeped in rural experience, with knowledge of the traditions of both Ayrshire and his father's native north east.

This essay will explore one small dimension of Burns' use of the rural year and its traditionary associations as a basis for the creation of his trademark, the evocation of a universal mood or experience, apparently realized in a particular context, but on closer examination not to be located within it. In the discussion that follows, I will examine Burns's use of two trees with a long set of associations in 
Scottish and European traditions, with the intention of demonstrating how Burns uses the inherited connotations of the plants and their seasons in literature and wider cultural traditions to reimagine the role of the poet and lover in nature and to frame memory and express aspiration beyond possibility. These approaches to evoking poetic moods, the moods of fulfillment, loss and aspiration, can be seen in the symbolic use he made of the birk (birch) and hawthorn in particular.

The hawthorn had both intense religious and amatory associations. Christ was of course crowned with thorns, and Charlemagne was supposed to have "knelt in reverence before the Crown of Thorns" upon which "it suddenly burst into bloom, and the scent of Hawthorn filled the air” (Porteous (2002), 280). The tree had supposedly been brought to the British Isles to Glastonbury by Joseph of Arimathea (Hemery and Simblet (2014), 131); it was good luck to have its May flowers (Hawthorn was the May-tree) outside the house, bad luck to carry them indoors. Throughout Europe and beyond, the tree had long had aphrodisiacal associations, and its blossoms might be carried to weddings; before the shift to the Gregorian calendar, the common hawthorn blossomed around 1 May (Phillips (1978), 108), and so was often associated with May Day festivities and recognition of marriage or fertility ((as in Allan Ramsay’s “Polwarth, on the Green”) (the scarcer midland hawthorn bloomed slightly earlier) (Rodger, Stokes and Ogilvie (2006), 68). In Scotland, Hawthorn was a "trysting-place for the Faeries" (Thomas the Rymer had allegedly met their Queen while by a hawthorn bush (Henderson and Cowan (2001), 69)), while a solitary stunted thorn tree on its own in a field was "considered to be bewitched", and farmers would leave it be (Porteous (2002), 85, 279). In a 1576 witch trial in Burns’s home county, Bessy Dunlop had confirmed the tree as a trysting place for fairies, and it was also associated with witches (Henderson and Cowan (2001), 41, 137). The tree was 
often planted near running water, was thought to protect wells and springs, and a girl who pulled the hawthorn blossom might dream of her future husband in consequence. Burns' own familiarity with folklore of this kind was evident in a wide range of his poetry. Hawthorn trees were on the one hand a symbol of Christ's suffering or of love and protection, on the other a feared tree of "sinister character" which smelt of the plague, was unlucky to have indoors and was on occasion associated with witches (McNeill (1989), 84); its “curious scent, trimethylamine...is present in the smell of sex and putrefaction” (Fisher, 56). From 1750, as Burns may well have known, common (and English) hawthorn hedges were used extensively in the enclosure of land, with some 200000 miles of such Quickset hedges planted over the following century in the British Isles. The hawthorn had in any event been used frequently for hedging for centuries, and so was associated with boundaries in the countryside, just as it fulfilled a liminal condition in protecting the household. The tree provided a threshold between the realms of nature and supernature, rationality and witchcraft, and-as in Dunbar’s “Treatise of the Twa Mariit Wemen and the Wedo”-respectable surface appearances and underlying sexual realities (Campbell-Culver (2006), 147; Henderson and Cowan (2001), 40, 155-56). ${ }^{1}$ As we shall see, Burns’ more complex and metaphorical use of the hawthorn places it in this context in his poetry, but the poet's default use of the tree for literary reference was perhaps most closely aligned with that identified by Sir Jack Goody, that hawthorn is "associated with unregulated love in the fields” (Goody (1993), 256), and its use by Burns certainly suggests that he used this symbolism in an aware and extensible sense-the hawthorn underpins a significant amount of Burns' language of unrestrained rural sexuality. It was also key to the myth of Highland Mary which grew from the poet’s transitory relationship with Mary Campbell (1763-86). The hawthorn tree at Coilsfield was allegedly the favoured 
meeting place of Mary and the poet: "part of the thorn under which Burns and Highland Mary had many a happy interview" was a frequent kind of relic ware in the nineteenth century, where small objects were made as souvenirs out of materials from places infused with the poet' s charisma (Pittock and Mackay (2012), 197-98).

The birch or birk-in Scotland, usually the silver or downy birch, though the river birch had been introduced from North America in 1736- had both similar and different associations. Like hawthorn, birk warded off evil spirits if set outside a house, but was unlucky to carry indoors. It was, like hawthorn, a tree of renewal and love: "bring me true love” might be written on its strips. It was also a tree of resurrection, although 'seeing a green birch in a dream presaged ill' (Darwin (2008), 85). Birks are associated with the land of the dead, Tir na nÓg (Pittock and Mackay (2012), 200). In “The Wife of Usher’s Well”, the birk that grows “at the yetts o Paradise” (still outside them, notably, and therefore a threshold plant, even in heaven) is that of which the hats of her dead returning sons is made, and perhaps the means by which they become briefly incarnate for her. "Birks" are associated with the other world and with purification. The wife’s sons must return to Purgatory ("Gin we be missed oot o our place,/A sair pain we maun bide”), and the birk was burnt in the May Beltane fires, last held in Edinburgh in 1756 and no doubt more persistent elsewhere. These trees are signs of a briefly realized happiness of "secrecy and refuge” (Darwin (2008), 84), and perhaps also can represent an idealized version of this world, out of time, whose relentless grasp in reality awaits in "the winter of the year", theirs and ours. The "birk" (l. 16) that shades Mary and the speaker in the poem quoted at the opening of this essay is a sign of the otherworld, into which Mary Campbell, so briefly his love, has now travelled irremediably. 
In "Song-Compsed at Auchtertyre on Miss Euphemia Murray of Lentrose” ("Blythe, Blythe and merry was she” (Kinsley 179)), the "birken shaw” (l.2) marks an appearance of the birk as a sign of death and otherworldliness, not least because there is an almost certain intertextual reference to the murder of the girl's lover by the birks of Yarrow in William Hamilton of Bangour’s (1704-54) “The Braes of Yarrow”, itself building on many different traditional versions of the song. ${ }^{2}$ The "ghastly spectre” in Bangour's poem also evokes the supernaturalism of the birk. By contrast, Burns' "Phemie” (a diminutive in the Doric pastoral tradition for Miss Euphemia Murray of Lentrose) is a “bonier lass/Than braes o’ Yarrow ever saw”. She is no revenant, but a living promise of renewal with a "smile...like a simmer morn" with a step “As light's a bird upon a thorn”. The May flowering of the hawthorn as a sign of love and hope is clearly referenced and typified through her, but Phemie eludes any commitment: she represents the ever elusive but ever present promise of returning hope with spring, at one (briefly) with the hawthorn, transcending the tragic past of the birk's reminder of death at Yarrow and an world that perpetually eludes us elsewhere. In this deceptively simple poem, without personifying Euphemia as spring, Burns presents her as the epitome of its transience and its glory: "Blythe was she but and ben:/Blythe by the banks of Ern/And blythe in Glenturit glen”. It is by those "banks of Ern” she is like "a bird upon a thorn”, nesting on the hawthorn in spring like the blossom of the flower itself: for the death associated with Yarrow’s birks, Burns substitutes the birth and renewal of Ern's hawthorn. Phemie, so familiar yet so elusive, is both fully a young woman and a creature of omnipresent faery promise. The air, “Andrew an' his cutty gun”, with its established phallic reference, adds a delicately elusive hint of bawdry to the song, as is only fitting given Phemie's season. 
Burns was clearly fascinated by both birk and hawthorn, and this was far from the only poem or song he constructed round them. On 1 January 1789, he wrote to Mrs Dunlop looking forward to the "budding birk" and "hoary hawthorn" of the forthcoming spring (Campbell-Culver (2006), 129; Burns, Letters I:293). He associates both with love and its evanescence into otherworldly longing, an erotic Tir nan nOg.

In "Flow gently sweet Afton” (Kinsley 257), one of his most famous songs, Burns evokes the idea or mood of lost love through the collocation once again of river and birk, perhaps recalling "the birch of the waterfalls" as tree of traditional strength (McNeill (1989), 84). (Highland) Mary is the "slumbering Fair” of the song, which evokes a lost ideal, the inevitability of the passage of time (symbolized by the river, which flows not at the poet's command as the rhetoric of the song makes out, but despite it) and human fantasies about arresting it. Far from stemming "thy clear wave" with her purity and constancy, symbolized by the "snowy feet" which resist the "wanton waters", the river of time has carried Mary and the fantasies of the poet alike away. No bird-least of all "Ye wild whistling blackbirds in yon thorny den”, the heralds of fertility and spring (blackbirds indeed like the hawthorn)- can disturb the "slumbering Fair" among the "green braes" of Afton: she is dead and beyond sound. Green, the fairy colour, repeated three times in the song, evokes the idea that Mary has only been abducted from the world, not lost to it: it is part of a pattern of subtle connotations in Burns' language which render the subject of the poem intimately familiar, and yet inaccessibly distant, a dream of a magic, lost realm. "Flow”, repeated six times at the beginning and end of the song, reminds the reader of the 
nullity of this realm in reality: the river, and time, are always moving on for us inside our hearts and lives, if not so apparently for nature outside them. The verb "to flow" is illusorily presented as an imperative when it is in reality inevitable: language itself deceives us with the dream of controlling what we indeed must suffer. Yet there is a central if evanescent unity of the lovers in the song, when "The sweet scented birk shades my Mary and me”. Here the birch tree symbolizes death and the other worldly just as directly as it does in "The Braes of Yarrow”, but the language of death and suffering is represented as mediated through the apprehensions of the sentimental era. Burns' "birk” here is not the sign of guaranteed suffering and dissolution, the semiosis of severance from the world; it is a place where he can visit and be with Mary in his imagination, even though the "shade" of that imagination is not from the summer sun but that of intervenient death. The birk has become a sign not of the otherworldly merely, but of the aspiration realizable only in imagination, the promise (however elusive) of a love which can be longed for but never realized, the threshold tree between life and death, consummation and the elusive persistence of passion, which allows the space where the poet can reimagine an absent relationship.

“The Birks of Aberfeldy” (Kinsley 170) is perhaps Burns’ most famous song which utilizes the birk in this way. It was written in Kenmore Inn on 30 August 1787, although it is of course derived from an earlier song, dealing with “Abergeldie”, a location in north east Scotland. Here Burns takes the aspirational language of longing in the "birk” one stage further. “The foamy stream’s” persistent roaring fall is a perpetual promise of consummation in the deep cleft of the Moness burn, where "The hoary cliffs are crown'd with flowers/White o'er the linns the burnie pours”, in the fertile exchange of the potent interaction of the landscape with the water. The birks themselves are wet "with misty showers", but the act of love outlined in the 
conjunction and shape of the landscape is otherworldly not because it is supernatural but because it is sublime. Yet the poet is not a spectator only: his eye, like Wordsworth’s in “Tintern Abbey”, half creates and half renews the landscape in front of him and aligns it to human love, though it in itself is grander and more permanent than any human love can be. The woman he calls for: "Bony lassie will ye go...to the birks of Aberfeldey" has no being outside that aspirational mood. The "birks" are a different place, another life, a place where love can be seen as a type and not its occasions merely. The "lassie" has no name: she is every lassie, any lassie and no lassie, whoever Burns’ biographers may perceive her to be. "Supremely blest wi’ love and thee", the poet was on his own "standing under the falls of Aberfeldy, at, or near, Moness” (Cromek (1808), 237), when the song was written. The lass with no name is called for only, “will ye go” ? She never comes: any one coming would be evanescent, Aberfeldy's birks are permanent. In this landscape of passionate boiling waters and the fertility they feed in a perpetual act of love, the landscape’s performance symbolizes eternal human longing, not its particular manifestation. On the threshold of what manifests human desire and what goes far beyond it in permanency and power, their presence has the capacity to remind of absence. Despite the soothing, incantatory nature of the song, the birks are at the centre of it, not the woman who is being addressed.

In “The Banks of Nith” (Kinsley 229), the "bounding hawthorns””are aligned with the wantoning "lambkins", alike symbols of the flowering of spring in May, the speed of the blossom's arrival and spread paralleling the rapidity with which lambs can walk, in a poem which nonetheless contrasts the ever recurring vigour of the lambs and spring thorn with the "friends of early days" and promise lost which will 
never return. The same process is at work in “Song-“ (Kinsley 409) where Willie’s wife mourns his absence in the army ("While my dear lad maun face his faes/Far, far frae me and Logan braes” (ll. 7-8)), an absence mocked for her wintry heart which has “Nae Mate to help, nae Mate to cheer” by” “yon milkwhite hawthorn bush” where “Amang her nestlings sits the thrush” (ll. 17-18, 22). The thrush, like the blackbird, is indeed a visitant to the hawthorn in spring (Hemery and Simblet [2014], 132), and is a symbol of freedom and good relationships, the very things that “Men o' State” who "brethren rouse in deadly hate" have deprived the woman of (ll. 25-26). She longs; the river "sweetly" glides; for nature time is cyclical and the seasons bring return; for her it is linear, and has brought her only to "widowed nights and joyless days" (line 23). She may hope for a cyclical return ("soon may Peace bring happy days” (line 31)), but all her language suggests that she suspects that such a hope is vain. The hawthorn flowers in the world outside: but that is the world of love and renewal. Engaging with it and internalizing that world reveals the doubleness of it: on the threshold of love and its seasonal couplings it is at one with us; brought into the home of the heart, the depth of passion shows the incompatibility of human and natural time, linear and cyclical time, loss and renewal. Indoors, in human space, the hawthorn-like the hats of birk- is the harbinger of destruction and severance from the life of which outdoors, in natural space, it seems the perpetual promise.

This is more intensely realized in "A Song” ("Thou lingering star with lessening ray” (Kinsley 274)) which mourns (or seems to mourn: Burns as so often intensifies a mood without altogether persuading one of the force of emotion) the loss of “My Mary, dear, departed Shade”. The poet conjures up an image of their (probably last) meeting in May 1786, when “The fragrant birch, and hawthorn hoar,/Twined, am'rous round the raptured scene”, both suggestive of renewal and 
fertility and the imminence of its dissolution: liminal, threshold trees as they are, the evoked scene suggests both the fulfilment of love and its proximate end at the very moment at which it reaches for its perpetuation. The outer twining of the trees remains; the inner rapture vanishes.

The same process can be viewed at work in a number of different contexts: for example in "The bonie lad that's far awa” (Kinsley 348) where "the birken shaw" promises the return of "him that's far awa” (ll. 18-20), a return, whether of king or lover, which is indefinitely delayed in (originally often Jacobite) songs of this kind, as Burns knew. The “cleeding” of “spring” will mock the absence of the woman's transient love, of which her status as a single mother (“my young babie will be born”) is the only evidence. In “The Posie” (Kinsley 372), the pulled hawthorn is part of an offering of every seasonal flower to "my ain dear May”, apparently a woman but not one who can be characterized except in terms of the season and its name, so perhaps once again simply a disembodied and evoked emotion, an intensity of feeling less personal than hormonal. As so often, the less specific Burns is about detail, the more successfully he voices an emotion that all can share. The nameless "Maid" of "As I went out ae May morning” (Kinsley 384) “learn’d...That she was not a single hour too young” for sexual relations “amang yon birks and hawthorns green” (ll. 13, 15): the encounter is a kind of brief, momentary abduction into the world of faery green, across the threshold of her experience, where time seems suspended. Since she has already wisely said that "To be your bride I am too young,/To be your loun wad shame my kin” (1l.9-10), the future commitment of her lover has been well charted. But since she doesn't even have a name in the poem in that lover's voice, who can be surprised ? The commitment of her lover at the end of the song ("For ye never shall 
rue what ye now hae done !” (1. 32)), with its unusual promise of the reconciliation of cyclical time with linear commitment, is a welcome surprise indeed.

Thus the presence of hawthorn or birk in Burns’ poetry often either represents transient and anonymous fulfilment, at one with the season, or the absence and loss associated with changing human lives and the desire to domesticate the liminal and transient energies of love. The beloved is often absent, either severed by death or replaced by a mood of love, almost a seasonal celebration without specific reference, no matter how specific such reference might appear. In Kinsley 280, where “Green sleeves and tartan ties/ Mark my true love where she lies”, the beloved is (as so often) not characterized in any more detail. Rather:

Be it by the chrystal burn,

Be it by the milk-white thorn,

I shall rouse her in the morn, My fiddle and I thegither.

The thorn is white because it is May; Burns' evocation of his own song or poem (the fiddle) is also an evocation of his sexuality. The "rousing” is an awakening, but also an arousing, more than that, an arousal. Yet the love being present is veiled in the enveloping mood of the emotion: nothing is specific, nothing personal. In the season of the "milk-white thorn”, the fiddle plays, the poet speaks, the man makes love: to whom ? Perhaps to hardly anyone more than the ideal of returning love, life and mystery, the spring which in a way he himself personifies and yet in a way which falls short of the crudity of such allegory to the modern mind. The hawthorn is the voice of the people, the popular recourse to love, hope and superstition which the poet 
emblemizes and editorializes at the same time, manipulating some of the simplest vegetative symbols of emotion much more knowingly than the simple countryman he purports to be.

This aspirational use is again present in the "Lament of Mary Queen of Scots on the Approach of Spring” (Kinsley 316), where the imprisoned Queen recounts from her point of view her separation from all quotidian relationships and carefree love, such as those that are enjoyed by "the meanest hind in fair Scotland" when "The hawthorn's budding in the glen” (lines 19, 21). What lies in wait for her is only "the narrow house of death" on which "the next flowers, that deck the spring” will bloom (ll. 53, 55). The tragedy of lost love in “The Banks o’ Doon” (Kinsley 328B) is less ultimately bitter, but the poet makes his customary point about the displacement of love and happiness from the flowers that seem to signify its arrival more explicitly than usual:

Thou'll break my heart, thou warbling bird,

That wantons thro' the flowering thorn:

Thou minds me o’ departed joys,

Departed, never to return.-

Once again, the riverside setting of the hawthorn is a reminder of the passing of time and the loss it brings, and a disassociation of the speaker from the blossoming thorn's promise of love, hope and renewal, mocked for him by the wantoning bird. As is usually the case, the lost and absent love is not named: she is rather a mood.

The hawthorn under which Burns met Mary Campbell seems to be a much more specific reference: in a way, it sets the relationship with Highland Mary rhetorically apart in Burns' poetry. Yet, even here, things may not be as they appear. The poet and Mary’ s last meeting ( “the last Fareweel/O’ my sweet Highland 
Mary” (Kinsley 389)) was on 14 May 1786 by the Gregorian calendar, just at the very moment when hawthorn might begin to be in bloom: so the moment of his final parting with his beloved is a liminal exit just as the hawthorn is at a liminal entrance into life, love and fertility. Hence the passion inspired by the "gay, green birk" and the "rich hawthorn' s blossom" is one which is transient in its "golden Hours" on their route to “fell Death' s untimely frost” (lines 9-10, 13, 21). In “Highland Mary” , the hawthorn does not the guard the threshold of an entrance into domestic life and private bliss, but of an exit from it. Mary herself almost instantly becomes lost to the poet, and thus at once enters into the realm of disembodied emotion which creates mood. While hawthorn's status as the "May-tree" links it with blossom and fertility, "the fact that it was traditionally unlucky to take it indoors might suggest the snatched, symbolic and unrealisable nature of Burns’s and Highland Mary’s relationship" (Pittock and Mackay (2012), 200-01). Indoors is of course the domestic realm, where human beings attempt to perpetuate the transience of cyclical love into a permanent linear reality. But Highland Mary was to play a more special role in

Burns’ s writing than simply a symbol of disembodied love, an absent objective correlative for emotion. She was also to have a quasi mystical status. One of the hawthorn’ s names was "Mary’s Mayflower" after Our Lady, who is of course in heaven, like the "Mary" of the poet. The whole "last interview" story in Burns's poem may thus be a symbolic reconstruction: Burns’s "Highland Mary" may have been from the beginning both Fairy Queen and the Virgin, both spéirbhean (skywoman, the miraculous sidhe apparition in Irish aisling poetry) and Our Lady. Burns's mention of "the hawthorn's blossom" invites such associations, while the 
"birk" , the tree of the other world, and of unrealisable and lost aspiration indicates a world to which the poet will never return and cannot now reach, an image of unattainable prospect as much as admired retrospect, and in itself a guarantor of Foucault's law of cultural scarcity (loi de rareté) linked to lost memories and displaced places. The genealogy of May as Mary’s month, the hawthorn as Mary’s tree and the tree itself as a place of rendezvous for men with a beloved, found in the Scottish song tradition in a number of writers, alike place Burns' s "Highland Mary " in the same category of typological emotion rather than individuated love for which he has been using birch and hawthorn throughout his writing.

Burns can also use the symbolism of the birk and hawthorn in a much more direct and unmediated sense, as in "Cauld is the e'enin blast... When birks are bare at Yule” (Kinsley 601), in which the sexual insatiability of “bonie Peg a Ramsey” is symbolized by the impossibility of confining her need for "grist to her mill" to the season of fertility and spring: she is always interested, whatever the weather. In "The lea-rig-“ (Kinsley 392), the “dew” of the “scented birks” (ll 5-6) presages consummation for the lover who "roves" in "mirkest glen”, and whose virility, no matter how "wet" the night becomes, will never "weary". Here, although the woman is not named save as a "jo", the repeated act of love is not displaced into the landscape of the birks, but symbolized by it (lines 2, 9-10, 13-14). It is merely a merry coupling, and thus at one with the seasons, not trying to perpetuate them: a moment of love and recognition, not unlike the "sweet lass,/Sweet as yon hawthorn’s blossom” at the moment of recognition in Kinsley 406 in a poem which at least presents the possibility of a happy ending to the situation outlined in "Logan Braes", or the moment of impulsive passion symbolized in "the milkwhite thorn" in "Lassie wi' the 
lintwhite locks” (Kinsley 466). “Scotch Song” (Kinsley 502) makes this symbolism more explicit: the poet is likened to a "wanton trout" in the "careless stream" of life, who thinks to evade "the angler" (of time ?) under "the shady thorn” (ll. 9-15), but in seeking to perpetuate the season, "witching love, in luckless hour/Made me the thrall o’ care” (ll. 31-32). Much more happy is the position of Bessy in "Bessy and her spinning wheel” (Kinsley 365), where she enjoys the moment, at one with "The scented birk and hawthorn white” and full of "peace and pleasure”, longing neither for power nor for anything else which is absent (ll. 11, 31).

A simpler image of the hawthorn as the inspirited renewal of spring is to be found in "On Cessnock banks a lassie dwells" (Kinsley 11), where the subject is “spotless, like the flow'ring thorn/With flowers so white and leaves so green...Her looks are like the vernal May”. But if the girl of Cessnock is related to the hawthorn by simile, in “The Vision” (Kinsley 62), the hawthorn is a metaphor for the poetic self, who will triumph despite being mired in social and financial inferiority:

'Tho' large, the forest’s Monarch throws

'His army shade,

'Yet green the juicy Hawthorn grows.

'Adown the glade.

'Then never murmur nor repine;

'Strive in thy humble sphere to shine...(lines 255-60)

The poet emerges from the social shades to triumph because the poetic message is the hawthorn's: the mystery of faery (green is the fairy colour), the return of spring and verdure, fertility, renewal and the promise of love. Despite the high cultural baggage 
of “The Vision” as a poem about Burns’ Muse, neatly supported by a reference to the aisling tradition of Gaelic verse, the core reference is to the poet's triumph as resting on none of these accessories of genre or register, but on the straightforward ability to represent, to personify, to be the mood of love and renewal, a mood which cannot be safely prolonged. No specifics, no commitment, no politics: just a promise to "touch the heart” (“Epistle to John Lapraik” (Kinsley 57), 1. 78), to evoke an emotional mood as passionate and imprecise as music. This is perhaps why Allan Ramsay, who is alluded to next in the Lapraik Epistle for his “spunk" of native glee, is referred to elsewhere by Burns (“Sketch”- Kinsley 82), as characterized by “hawthorns gray”. Burns identified with Ramsay as a poet of mood, humour and passion: and this is seen in the fact that in very different poems, both poets are associated with the love and mystery of the hawthorn. These are Burns' “woodnotes wild”, “ae spark o’ Nature’s fire” (1. 73) to set against

A set o' dull, conceited Hashes,

Confuse their brains in Colledge-classes!

They gang in stirks, and come out Asses,

Plain truth to speak;

An' syne they think to climb Parnassus

By dint o' Greek! (“Epistle to J. Lapraik”, ll. 67-72)

Of course, even here Burns is typically slippery, as we have already seen from his own interest in Greek. Yet the central message is surely unmistakable: there is no love, no generation, no nature here: Parnassus is a word on a page in a foreign language, not a place of resort. The students are stirks when they go in, and thus infertile (stirks are for slaughter not breeding), and have become asses when they 
come out. From being incapable of sexual creation, they have become incapable of its poetic or artistic equivalent: Burns has chosen his metaphorical animals well.

Learning disassociates us from nature and from nature’s most essential processes. In the poetry of Robert Burns, the simple traditions of birk and hawthorn evoke love and death, transient fulfilment and its everlasting boundaries, while the poet also voices the poignancy of the loss attendant on the human desire to perpetuate emotion and to own the seasonal, cyclical time of what is to be in reality their linear and in the end fatal decline. Only the sensations of loss, absence and impermanency can result from carrying the threshold trees indoors. These are powerful sentiments, and very much those of the first, as of the "last Romantics": in its use of nature as an apparently endlessly renewable source of opportunity we are forever losing sight of, Yeats’s “Wild Swans at Coole” revisits Burns’ approach in a different context, and arguably a more solipsistic one. Burns’ status as the spokesman for a tradition from which he also stands apart is not unlike Yeats's: but it is more frequently underestimated. It is perhaps no coincidence that Yeats’s favourite Burns lines were

The wan moon sets behind the white wave And time is setting with me, Oh: (Kinsley 403)

Like the moon and the wave, the birk's and hawthorn blossom's white encourage the hope of endless and illimitable possibility on the threshold of life, a blank canvas of fertility and hope. And yet they tell of its opposite. 


\section{References}

The Poems and Songs of Robert Burns, ed. James Kinsley, 3 vols. Oxford: Oxford UP, 1968.

The Letters of Robert Burns. Eds J. de Lancey Ferguson and G. Ross Roy. Oxford: Ocford UP, 1985.

The Oxford Edition of the Works of Robert Burns Volume I Commonplace Books, Tour Journals, and Miscellaneous Prose, ed. Nigel Leask. Oxford: Oxford UP, 2014.

Campbell-Culver, Maggie. A Passion for Trees: The Legacy of John Evelyn. London: Transworld, 2006.

Cromek, R.H. Reliques of Robert Burns.London: Cadell and Davies, 1817 [1808].

Darwin, Tess. The Scots Herbal: The Plant Lore of Scotland. Edinburgh: Birlinn, 2008 [1996].

Fisher, Celia. The Medieval Flower Book. London: British Library, n.d.

Goody, Jack. The Culture of Flowers. Cambridge: Cambridge UP, 1993.

Hemery, Gabriel and Simblet, Sarah. The New Sylva. London: Bloomsbury, n.d. [2014].

Henderson, Lizanne and Cowan, Edward J. Scottish Fairy Belief. East Linton: Tuckwell Press, 2001.

McNeill, F.Marian. The Silver Bough. Edinburgh: Canongate, 1989 [1956].

Phillips, Roger. Trees in Britain Europe and North America. London: Pan, 1978.Pittock, Murray.

“Robert Burns and British Poetry”, Proceedings of the British Academy 121 (2003), 191-211.

. “’The Real Language of Men’: Fa’s Speerin ? Burns and the Scottish Romantic

Vernacular”, in David Sergeant and Fiona Stafford (eds), Burns and Other Poets, (Edinburgh: Edinburgh University Press, 2012), 91-106.

Pittock, Murray and Mackay, Pauline. 'Highland Mary: Objects and Memories’. Romanticism 18 (2) (2012), 191-203.

Porteous, Alexander. The Forest in Folklore and Mythology. Mineola: Dover, 2002 [1928].

Rodger, Donald, Stokes, John and Ogilvie, James. Heritage Trees of Scotland. Edinburgh: Forestry 
Commission Scotland, 2006.

${ }^{1}$ John Burnett, in conversation 26 March 2011; Fiona Stafford, 'Hawthorn’, Radio 4, 20 May 2014.

${ }^{2}$ See for example, https://www.youtube.com/watch?v=HRu8w4OTOYQ. 